\title{
A Democratic Culture? Women, Citizenship and Subscriptional Texts in Early Modern England
}

The social reformer and women's suffrage campaigner Susan B. Anthony wrote that as women in nineteenth-century America could 'neither take the ballot or the bullet' to settle political questions, the 'right to petition is one sacred right which we ought not to neglect'. ${ }^{1}$ Women's petitioning activity has often been linked to the suffrage movement: Ellen McArthur, who undertook the first serious scholarly work on women's petitioning in the seventeenth century was a suffragist. ${ }^{2}$ Both Susan Zaeske for the United States and Clare Midgley for Britain have argued that nineteenth-century petitioning campaigns for the abolition of slavery provided women with opportunities to advance broader claims about their rights as citizens. As Zaeske puts it

By petitioning, women not only helped bring about an end to slavery, but they also made important strides towards securing their own rights and transforming the political identity of woman into that of active national citizen. $^{3}$

Similar claims have been made for petitioning in the early modern period. The growth of mass printed petitions during the civil war has been seen by David Zaret as facilitating the emergence of a democratic political culture. In a bold conclusion, Zaret argued that Leveller ideas, as articulated in John Lilburne's England's New Chains Discovered (1649), demonstrate a movement

on the brink of a formal platform for a liberal-democratic model of the political order as experience with the political petitioning stimulated new ideas about the centrality of public opinion as the ultimate ground of legitimacy for a legislative agenda. ${ }^{4}$

\footnotetext{
${ }^{1}$ Quoted in Susan Zaeske, Signatures of Citizenship: Petitioning, Antislavery, \& Women's Political Identity (Chapel Hill: University of North Carolina Press, 2003), p. 10.

2 Noted in Amanda Jane Whiting, Women and Petitioning in the Seventeenth-Century Revolution: Deference, Difference and Dissent (Turnhout: Brepols, 2015), p. 20. For other works on women's petitioning in the Civil Wars see Andrea Button, 'Royalist Women Petitioners in South-West England, 1655-1662', The Seventeenth Century, 15:1 (2000), pp. 53-66; Ann Marie McEntee, 'The [un]civill-sisterhood of oranges and lemons": Female Petitioners and Demonstrators, 1642-1653', in James Holstun (ed.), Pamphlet Wars: Prose in the English Revolution (London: Routledge, 1992), pp. 92-111 and the references to the work of Ann Hughes, Melissa Mowry and Hannah Worthen below.

${ }^{3}$ Zaeske, Signatures of Citizenship, p. 175. Clare Midgley, Women Against Slavery. The British Campaigns 1780-1870 (London: Routledge, 1992).

${ }^{4}$ David Zaret, Origins of Democratic Culture: Printing, Petitions, and the Public Sphere in Early-Modern England (Princeton: Princeton University Press, 2000), p. 265.
}

Accepted manuscript version of E. Vallance, 'A Democratic Culture? Women, Citizenship and Subscriptional Texts in Early Modern England', in Democracy and Anti-democracy in Early Modern England, 1603-1689, ed. C. Cuttica and M. Peltonen (Brill, Leiden, 2019), ch. 12 
If not directly connected to the franchise as in the modern period, women's participation in subscriptional activity has often been viewed as an assertion of citizenship and the frequency of women's involvement in petitioning and oath-taking as evidence of an expanded early modern public sphere. John Walter has argued that the taking of oaths of loyalty by women during the civil war challenged:

one of the fundamental assumptions of early modern political culture that it was male, married, propertied householders who claimed a public political identity and that their household dependants were subsumed within that identity. ${ }^{5}$

For Sara Mendelson and Patricia Crawford, women's subscriptions to Parliamentarian oaths and covenants in the 1650 s sometimes represented a 'self-conscious assertion of covenantal citizenship'. ${ }^{6}$ In his recent book on the 1641 Protestation Walter has found evidence that the presence of women on subscription returns may be explained by their own political activism: Giles Randall, the minister of Eaton, Huntingdonshire recorded that the Protestation had been taken by women in his parish on account of 'their neer \& Equall interest (as they doe conceive) unto the cause being as free \& voluntary in the same as ourselves'. ${ }^{7}$ Both Steven Pincus and Mark Knights have suggested that the immense number of subscriptions to the 1696 Association in defence of William III are indicative of a much enlarged political nation. For Pincus, 'the number of subscriptions in 1696 suggests that most English men and some women assigned themselves a political role'. ${ }^{8}$ My own research on the 1723 oaths of allegiance to George I has suggested that the large numbers of women subscribers on these returns (typically between a quarter and a third of the names on each list) was partly a reflection of the increasing prominence of women in early Hanoverian politics. ${ }^{9}$

In this chapter, however, I want to challenge this perceived relationship between subscriptional activity, notions of citizenship and a more democratic political culture. Some historians, such as Ann Hughes, have struck an important note of caution regarding treating

\footnotetext{
5 John Walter, 'The English People and the English Revolution Revisited', History Workshop Journal, 61:1 (2006), 171-82, p. 179.

${ }^{6}$ Sara Mendelson and Patricia Crawford, Women in Early Modern England (Oxford: Oxford University Press, 1998), p. 399.

7 John Walter, Covenanting Citizens: The Protestation Oath and Popular Political Culture in the English Revolution (Oxford: Oxford University Press, 2016), p. 206.

${ }^{8}$ Steven Pincus, 1688: The First Modern Revolution, (New Haven: Yale University Press, 2009), p. 468; Mark Knights, Representation and Misrepresentation in Later Stuart Britain: Partisanship and Political Culture (Oxford: Oxford University Press, 2005), pp. 154-60.

${ }^{9}$ Edward Vallance, 'Women, Politics and 1723 Oaths of Allegiance to George I', Historical Journal, 59:4 (2016), pp. 975-99.
} 
women's petitioning 'solely within a history of female or even proto-feminist activism'.10 Hughes has noted how, even in the petitions of Leveller women in 1649 and 1653, traditional feminine roles as wives, mothers and homemakers were emphasised in advancing claims within these texts. ${ }^{11}$ Most recently, Amanda Whiting has urged historians to pay more attention to the constraining effect of petitioning as a form. Whiting argues that, viewed as a genre, all petitioning was 'feminine' in the sense of being typically conveyed through a language of deference and weakness. ${ }^{12}$ Whiting follows Lex Heerma van Voss in seeing petitioning as a form of political activity that, while it could be seen as conferring rights on the petitioners, it also involved displays of political loyalty and obedience which conferred legitimacy in this case on the English parliament. ${ }^{13}$ As Milton wrote in An Apology for Smectymnuus (1642):

the meanest artisans and labourers, at other times also women, and often the younger sort of servants assembling with their complaints, and that sometimes in a less humble guise then for petitioners, have gone with confidence, that neither their meanesse would be rejected, nor their simplicity contemn'd, nor yet their urgency distaste either by the dignity, wisdome, or moderation of that supreme Senate; nor did they depart unsatisfi'd. ${ }^{14}$

Whiting concludes that even when a more assertive language of rights emerged in women's petitions, as those from Leveller women, this had a paradoxically counter-productive impact on feminine political agency. The 'rights bearing' citizen entailed a masculine subjectivity and as a consequence it was much harder for women to incorporate themselves into this discourse. ${ }^{15}$

Whiting's conclusions offer a reminder that petitioning and democracy, when viewed from the perspective of contemporary history, have often been seen as enjoying an inverse relationship with each other: as mass democracy developed, so, it is argued, the value of petitioning diminished. The revival of petitioning in the $21^{\text {st }}$ century with the e-petition might, in turn, be regarded as a symptom of failing health of liberal democracies. Indeed,

\footnotetext{
${ }^{10}$ Ann Hughes, Gender in the English Revolution (London: Routledge, 2012), p. 54.

11 Ann Hughes, 'Gender and Politics in Leveller Literature', in Susan D. Amussen and Mark Kishlansky (eds), Political Culture and Cultural Politics in Early Modern England (Manchester: Manchester University Press, 1995), pp. 162-88.

${ }^{12}$ Whiting, Women and Petitioning, p. 131.

13 Lex Heerma van Voss, 'Introduction', in Lex Heerma van Voss (ed.), Petitions in Social History (Cambridge: Cambridge University Press, 2002), pp. 1-10.

${ }^{14}$ Whiting, Women and Petitioning, p. 207.

15 Ibid., p. 300.
}

Accepted manuscript version of E. Vallance, 'A Democratic Culture? Women, Citizenship and Subscriptional Texts in Early Modern England', in Democracy and Anti-democracy in Early Modern England, 1603-1689, ed. C. Cuttica and M. Peltonen (Brill, Leiden, 2019), ch. 12 
Brodie Waddell has noted that petitioning was a form of political communication perfectly suited to societies which valued equity but not equality: submissive and supplicatory, the petitionary form could be used by men and women, citizen and non-citizen alike. ${ }^{16}$ Even the unfree could petition: the earl of Warwick received a petition from America from 'one of my Negroes...that his wife may live with him', a request that the earl treated sympathetically, thinking it was 'full of reason'. ${ }^{17}$

In this chapter, I will argue that we can best understand why women were or were not present on early modern subscriptional texts (petitions, addresses, oaths) by reading these sources not as vehicles for articulating claims to citizenship but as devices for political, military and economic mobilisation and as a media for expressing discourses of loyalty and disloyalty. Here I am following recent work by Michael Braddick and most importantly Tom Leng on mobilisation in the civil wars. ${ }^{18}$ Leng notes that subscriptional devices such as the Protestation of 1641 certainly endowed the subscribers with political agency. This agency, however, was yoked not to a language of rights but to an emotionally-laden discourse of political and religious difference, discriminating between the 'well-affected' subscribers from the 'malignants' who refused the Protestation and subsequent oaths and covenants. Leng's interpretation of political language in the 1640s chimes with broader historical and philosophical explorations of loyalty which have, in Judith Shklar's words, identified it as a 'deeply affective and not primarily rational' quality. ${ }^{19}$ Subscribing to these loyalty tests carried obligations: to denounce those who opposed them; to take up arms against those who might threaten their success; and to be watchful for those in their community who were

${ }^{16}$ Brodie Waddell, God, Duty and Community in English Economic Life 1660-1720 (Woodbridge: Boydell and Brewer, 2012), esp. pp. 128-37.

${ }^{17}$ Quoted in Zaret, Origins of Democratic Culture, p. 86. For later petitioning by the slaves see Zaeske, Signatures of Citizenship, pp. 78-9; Raymond C. Bailey, Popular Influence upon Public Policy: Petitioning in Eighteenth-Century Virginia (Westport CT: Greenwood, 1979), pp. 44-5.

${ }^{18}$ Michael Braddick, 'Mobilisation, Anxiety and Creativity in England during the 1640s', in John Morrow and Jonathan Scott (eds), Liberty, Authority, Formality: Political Ideas and Culture, 1600-1900 (Exeter. Imprint Academic, 2008), pp. 175-98; Michael Braddick, 'History, Liberty, Reformation and the Cause: Parliamentarian Military and Ideological Escalation in 1643', in Michael Braddick and David L. Smith (eds), The Experience of Revolution in Stuart Britain and Ireland: Essays for John Morrill (Cambridge: Cambridge University Press, 2011), ch. 6; Tom Leng, 'Citizens at the Door: Mobilising against Enemies in Civil-War London', in Journal of Historical Sociology Special Issue: Activism, Mobilisation and Political Engagement, ed. M. Braddick and G. Rivett, 28:1 (2015), pp. 26-48; Tom Leng, "The Meanings of "Malignancy": The Language of Enmity and the Construction of the Parliamentarian Cause in the English Revolution', Journal of British Studies, 53:4 (2014), pp. 835-58.

19 Judith N. Shklar, 'Obligation, Loyalty and Exile', in Judith N. Shklar. Political Thought and Political Thinkers, ed. S. Hoffman (Chicago and London: University of Chicago Press, 1998), ch. 3, p. 41; and for a valuable historical perspective see Matthew McCormack, 'Rethinking “Loyalty” in Eighteenth-Century Britain', Journal for Eighteenth-Century Studies, 35:3 (2012), pp. 407-21.

Accepted manuscript version of E. Vallance, 'A Democratic Culture? Women, Citizenship and Subscriptional Texts in Early Modern England', in Democracy and Anti-democracy in Early Modern England, 1603-1689, ed. C. Cuttica and M. Peltonen (Brill, Leiden, 2019), ch. 12 
backsliders or fifth columnists opposed to their terms. ${ }^{20}$ This emphasis on surveillance was also sustained by the context of anti-popish conspiracy theory which informed many of these devices from the Protestation to the 1696 Association. To return to the quotation from Giles Randall above, the women of Eaton were claiming an equal interest in a cause, not rights within a political community. The chapter will explore the omission of overt discussion of citizenship or rights in most women's petitions. The paper will then move on to discuss the almost complete lack of women from another subscriptional form - the loyal address, showing how this genre became a vehicle for anti-democratic rhetoric in the 1680 s - before finishing by exploring the significance of women subscribing to oaths of allegiance, specifically the 1696 Association in defence of William III.

Printed petitions from women are rare: Whiting has identified only 42 for the whole period from $1642-1660 .{ }^{21}$ It is worth stating that many of these petitions are satirical productions, including those published post-Restoration which connect to the Parliaments of women genre. Take for example the ribald mass petition from 'many thousand Country Mayds' published in 1647 and subscribed by such apocryphal figures as 'Abominable Besse, Butchers daughter' and 'Simpring Sara, the Sadlers daughter'. ${ }^{22}$ Or 'The City Dames Petition' supposedly signed by Mrs I Stradling, Ma. Lecher and D. Swivewell. ${ }^{23}$ The creation of mock lists of subscribers is in contrast to what Whiting notes is an almost complete absence of subscribers from more authentic productions. In the case of early modern English printed petitions, there is no clear evidence of the kind of subscriptional activity that Zaeske argued was important as an act of resistance in its own right and which, as an act of direct participation in the public sphere, emphasised women's political autonomy and confidence. ${ }^{24}$ Texts also mocked the participation of women in popular political activity: 'The petition of the Weamen of Middlesex', a satire on 'Root and Branch' petitions, had women objecting to

\footnotetext{
20 Leng, 'Citizens at the Door', p. 42.

${ }^{21}$ Whiting, Women and Petitioning, p. 14.

${ }^{22}$ To the Right Honourable the Ladies ordinary and extraordinary, assembled in parliament, now sitting in Spring Garden (1647). Unless otherwise stated, texts published pre-1700 were printed in London.

${ }^{23}$ The City-dames Petition in the Behalfe of the long afflicted by well-affected Cavaliers (1647), Thomason E. 409[12].

${ }^{24}$ Zaeske, Signatures of Citizenship, pp. 109-11. Though the pamphlet version of the April 1649 Leveller women's petition (see below) does include an instruction on p. 8 that 'All those Women that are Approvers hereof are desired to subscribe it, and to deliver in their Subscriptions to the women which will be appointd in every Ward and Division to receive the same, and to meet at Westminster Hall upon Monday the 23 of this instant April 1649, betwixt 8 and 9 of clock in the fore noon'.
}

Accepted manuscript version of E. Vallance, 'A Democratic Culture? Women, Citizenship and Subscriptional Texts in Early Modern England', in Democracy and Anti-democracy in Early Modern England, 1603-1689, ed. C. Cuttica and M. Peltonen (Brill, Leiden, 2019), ch. 12 
clerical surplices on the grounds that 'they '[the clergy'] must have them starched, to the great prejudice of the Lilly-white hands of good customed Landrasses'. ${ }^{25}$

Even in more authentic productions, explicit claims by women to political rights were rare. Only in the second women's petition on behalf of John Lilburne (1653) can we see a direct assertion of women's right to petition: 'That we cannot but be much saddled to see our undoubted Right of Petitioning with-held from us...We claim it as our right to have our Petitions heard' ${ }^{26}$ Elizabeth Lilburne's petition went further, arguing that her petition had to be heard on the grounds that the Parliament's power was fiduciary -'the GREAT TRUST reposed in you'. ${ }^{27}$ As Zaret has pointed out, however, the right to petition that was being asserted was not a 'right in the modern sense'. Instead, male and female petitioners were claiming access to a "privileged communicative space, analogous to privileges that follow admission to the "freedom" of a municipal corporation'. ${ }^{28}$ In general, moreover, women's petitions appear to have made their claims on the grounds of poverty, weakness and extremity of want. Even the strident statements regarding women's share in the commonwealth contained in the April 1649 Leveller women's petition were prefaced in the pamphlet rather than broadsheet edition with the statement that 'We are so over-prest, so over-whelmed in affliction, that we are not able to keep in our compass, to be bounded by the custom of our sex: for indeed we confess it is not our custom to adress ourselves to this House in the Public behalf' ${ }^{29}$

Despite the language of exception employed here, there can be no question, that women did petition Parliament and the Crown during the seventeenth century. An order from the Council of State issued on 4 August 1649 instructed the officers of the guard that 'no women who clamour upon the Council upon pretence of debts due to them from Parliament, be permitted to come within the walls of this House'. ${ }^{30}$ This activity was not peculiar to the 1640s and 1650s, and we can find collective petitions from women to the Privy Council

25 Thomason E. 180 [17] A2. The creation of mock catalogues of petitions, including those from women, also appears to have been a popular satirical genre, see A Catalogue of the Petitions, Ordered to be Drawn Up and Presented to the Honorable House at their next Session (London?,1693?) which include such texts as 'A Petition of the City Clergyman's Daughters, that Increase and Multiply be made the Eleventh Commandment', in A Collection of the Several late Petitions \&c. to the Honourable House (1693), reprinted as The Petitioners Monitor (1693).

${ }^{26}$ Thomason 669 fo. $17(36)$.

27 Thomason 669 fo.10 (186). Similar statements are made in the opening of Alice Rolph's petition (1648), Thomason 669 fo. 12 (73).

${ }^{28}$ Zaret, Origins of Democratic Culture, p. 88.

29 Thomason E551 [14].

${ }^{30}$ Calendar of State Papers Domestic: Interregnum, 1649-1650, ed. M. A. E. Green (London: HMSO, 1875), p. 262.

Accepted manuscript version of E. Vallance, 'A Democratic Culture? Women, Citizenship and Subscriptional Texts in Early Modern England', in Democracy and Anti-democracy in Early Modern England, 1603-1689, ed. C. Cuttica and M. Peltonen (Brill, Leiden, 2019), ch. 12 
throughout the 1600s. Most common are those from the wives of sailors captured and held as slaves in North Africa, some even claiming to be on behalf of thousands of women. ${ }^{31}$ Petitions to the crown even included those from women inventors - Amy Potter, widow, petitioned Charles II in 1678 for a royal patent for her invention of making woollen flanders, (a sort of tape lace with characteristic scalloped borders), an invention which she claimed would encourage observance of the recent act for burying in wool. The king ordered either the Attorney or Solicitor General to investigate the matter and advise the council on whether such a patent could be granted. ${ }^{32}$ As the work of Philip Loft has demonstrated, the House of Lords continued to receive and respond to women's petitions on economic matters into the late-seventeenth and early-eighteenth centuries. ${ }^{33}$ Neither was this kind of activity exceptional to Britain: women also petitioned in other European countries in the early modern period. ${ }^{34}$ This research suggests that we should see the tradition of satirical women's petitions, not as an example of the 'world turned upside down', but as extracting comedy from the breadth and ubiquity of feminine petitioning activity.

Women's petitioning was therefore licit provided that it was appropriately couched and delivered, and addressed areas that it was deemed acceptable for women to petition on, for example when the matter of the petition was related to their roles as wives, mothers, housekeepers, and even as tradeswomen. When women's petitions to Parliament met with a firm rebuke in 1643 and 1649, this was not on the grounds that they could not petition but that the matter of the petition did not concern them (as women). Even here, though, the prohibition on women engaging in overtly political petitioning was not hard and fast: as the quotation from Milton above suggests, political petitions from women were acceptable when they happened to conform to the prevailing political mood. Partisanship trumped citizenship.

This is evident in the case of other subscriptional forms, notably oaths, covenants and associations (which were, in turn, frequently connected to petitioning and addressing

\footnotetext{
31 The National Archives, Kew, hereafter TNA, SP 16/305 fo. 134 (undated but c. 1635) 'Petition of Clara Bowyer, Margaret Hall, Elizabeth Newland, with a thousand poor women more and upwards, to the King'. For these petitions see Nabil Matar, 'Wives, Captive Husbands and Turks: The First Women Petitioners in Caroline England', Explorations in Renaissance Culture, 23:1 (1997), pp. 111-28.

32 TNA SP 29/406 fo. 85, 'The humble petition of Amy Potter, widw'.

33 Philip Loft, 'Involving the Public: Parliament, Petitioning and the Language of Interest, 1688-1702', Journal of British Studies, 55:1 (2016), pp. 1-23.

${ }^{34}$ Penny Roberts, 'Huguenot Petitioning during the Wars of Religion', in Raymond A. Mentzer and Andrew Spicer (eds), Society and Culture in the Huguenot World, 1559-1685 (Cambridge: Cambridge University Press, 2002), ch. 5, pp. 73-4 though Roberts sees this petitioning activity as less overtly political than that initiated by women petitioners during the English civil wars.
}

Accepted manuscript version of E. Vallance, 'A Democratic Culture? Women, Citizenship and Subscriptional Texts in Early Modern England', in Democracy and Anti-democracy in Early Modern England, 1603-1689, ed. C. Cuttica and M. Peltonen (Brill, Leiden, 2019), ch. 12 
activity). ${ }^{35}$ John Walter has noted that some women may have subscribed the 1641 Protestation, a promise to defend 'the true Reformed Protestant Religion' which became a 'shibboleth' for the Parliamentarian cause, because of the imprecision of the Parliamentary orders explaining who should take this test: as the minister Giles Randall put it, 'from the indefinite words of the [Speaker's ] letter'. ${ }^{36}$ However, Walter also suggests that the lack of gender-specific language in the instructions given may have been intentional: in the original draft of the letter, the word 'men' was struck out. Walter conjectures that the threat of a Royalist coup and the prominence of women as activists in the Scottish revolution, may have led some English parliamentarians to see harnessing women's agency as vital to the cause. ${ }^{37}$ Similar reasoning, I have suggested, may also explain the large numbers of women subscribers to the 1723 oaths of allegiance. In this case, women had been prominent in antiHanoverian rioting, and anti-Jacobite legislation had targeted 'disaffected persons' (again, note the language of affect) of both genders. The oaths provided an opportunity to monitor the obedience of the Crown's female subjects as well as offer a useful display of women's public loyalty to the Hanoverian regime. ${ }^{38}$

Women, then, appear on these subscriptional texts when it appears that it was politically expedient to mobilise them. Including women in this activity did confer some (temporary) political agency upon them. However, though some male radicals in the 1640s (Lilburne, Winstanley) chose to interpret subscription to these tests as entering into a form of mutual political contract with Parliament, in which loyalty was given in return for the Parliament's defence of individual liberties, and we can occasionally find similar arguments made by women petitioners, most of the discussion around these texts emphasised instead the role of these devices in distinguishing between the loyal and the disloyal, the 'well-affected' against the disaffected or malignants. ${ }^{39}$

35 See, for example the connections between the Protestation, the Grand Remonstrance and the county petitions of 1641-2, Anthony Fletcher, The Outbreak of the English Civil War (Oxford: Oxford University Press, paperback edn with corrections, 1985), p. 208.

${ }^{36}$ Walter, Covenanting Citizens, p. 206.

${ }^{37}$ Ibid., p. 204. On the prominence of women, see Laura A. M. Stewart, Rethinking the Scottish Revolution: Covenanted Scotland, 1637-1651 (Oxford: Oxford University Press, 2016), esp. pp. 97-114. Activism by women was a feature of the post-Restoration Covenanting movement in Scotland: see Alan J. McSeveney, 'Non-conforming Presbyterian Women in Restoration Scotland: 1660-1679' (University of Strathclyde PhD thesis, 2006).

38 Vallance, 'Women, Politics and the 1723 Oaths', pp. 994-6.

${ }^{39}$ For radical interpretations, see Edward Vallance, Revolutionary England and the National Covenant: State Oaths, Protestantism and the Political Nation, 1553-1682 (Woodbridge: Boydell and Brewer, 2005), ch. 6.

Accepted manuscript version of E. Vallance, 'A Democratic Culture? Women, Citizenship and Subscriptional Texts in Early Modern England', in Democracy and Anti-democracy in Early Modern England, 1603-1689, ed. C. Cuttica and M. Peltonen (Brill, Leiden, 2019), ch. 12 
That it was partisanship that was the main driver of women's involvement in subscriptional culture is further indicated by the almost complete absence of women from another type of subscriptional text: the loyal address. Addresses shared many features with petitions: they were subscribed texts from a particular community addressed to authority (in the 1650s the Protector, after the Restoration the crown). However, unlike petitions, they were ostensibly not requests for action or the redress of grievances but expressions of congratulations or thanks. They did include pledges of loyalty but as an expression of the whole community rather than as a binding commitment on one individual. ${ }^{40}$ During the "Tory Reaction' (1681-1685), the texts of loyal addresses explicitly attacked 'popular' subscriptional forms such as mass petitions, oaths and covenants. Linking these devices to the upheaval of the civil wars, a number of the addresses issued in the wake of the 1683 Rye House Plot included direct attacks on democracy and popular government. The text issued by the borough of East Looe, Cornwall, prayed that they would 'never feel again the intolerable Plague of a Democratical Tyranny'. ${ }^{41}$ The address produced by the Middle Temple identified the conspiracy as the work of men of 'Fanatical, Atheistical and Republican Principles'. ${ }^{4}$ The address from the borough of Morpeth similarly described the plot as work of 'Democraticall, Seditious and Schismatical Spirits'. ${ }^{43}$ The Scots Corporation of London's address occasioned by the same plot spoke of their abhorrence of all 'Petitionings, Combinations, Leagues, Covenants, and Associations not Authorized by your Majesties Command'. ${ }^{44}$ The county of Cardigan, with the corporations of Cardigan and Aberystwyth, stated their detestation of all 'Seditious and Democratical Tenents' in their address. ${ }^{45}$ The address from Leicester promised to crush 'Rebellion and Faction' in whatever form it appeared whether in a 'malitious Libel, or Seditious Petition'. ${ }^{46}$ Other addresses identified religious assemblies (dissenting 'Conventicles') as 'fruitful Seminaries' of 'Sedition and Rebellion'. ${ }^{47}$ Some addresses latched upon English corporations as the 'Nurseries of

\footnotetext{
${ }^{40}$ For the loyal address in England see Knights, Representation and Misrepresentation, esp. ch. 3 and see also Mark Knights, 'Participation and Representation before Democracy: Petitions and Addresses in PreModern Britain', in Ian Shapiro, Susan C. Stokes, Elisabeth Jean Wood, and Alexander S. Kirshner (eds), Political Representation (Cambridge: Cambridge University Press, 2009), pp. 35-57 and Edward Vallance, Loyalty, Memory and Public Opinion in England, 1658-1727 (Manchester: Manchester University Press, forthcoming 2019).

${ }^{41}$ London Gazette, 17-20 September, 1683, no. 1861.

${ }^{42}$ London Gazette, 5-9 July, 1683, no. 1840.

${ }^{43}$ London Gazette, 27-30 August, 1683, no. 1855.

${ }^{44}$ London Gazette, 9-12 July, 1683, no. 1841.

${ }^{45}$ London Gazette, 27 September-1 October, 1683, no. 1864.

${ }^{46}$ London Gazette, 16-20 August, 1683, no. 1852.

${ }^{47}$ London Gazette, 26-30 July, 1683, no. 1846 (corporation of Warwick's address).
}

Accepted manuscript version of E. Vallance, 'A Democratic Culture? Women, Citizenship and Subscriptional Texts in Early Modern England', in Democracy and Anti-democracy in Early Modern England, 1603-1689, ed. C. Cuttica and M. Peltonen (Brill, Leiden, 2019), ch. 12 
Sedition' which had nurtured the plot: the address from Bury St Edmonds called for an inspection of English corporations to 'hinder them from being any longer the Receptacles of bad Men, or Engines to play Republican Zealots upon us'. Another Suffolk address, from the corporation of Eye, supported the Crown's quo warranto campaign, as the surrender of charters was necessary as boroughs had been 'contesting for men of Republican principles' ${ }^{48}$ It is also notable that, in contrast to earlier addressing campaigns, those addresses issued in abhorrence of the Rye House Plot rarely advertised themselves as being subscribed by large numbers of people. ${ }^{49}$

The loyal addresses issued during the 1680s represent the paradoxical example of a popular political form deployed specifically to attack other popular 'subscriptional texts' and the idea of popular government in general. There nonetheless remained subversive elements within these displays of mass loyalty: celebrating the loyalty of London apprentices involved prizing partisanship over age or status. ${ }^{50}$ But the loyalty being celebrated was that of men, even if young men. Women, on the other hand, appeared to be almost completely excluded from addressing activity. Unlike oath returns, surviving subscribed manuscript addresses, with only one exception, do not feature the names or signatures of women. The largest surviving manuscript address that I have identified, the 1658 address from Leicestershire to Richard Cromwell, contains around three thousand names. While a comparison of Hearth Tax records with the address suggests that large numbers of the subscribers came from the ranks of the 'just about managing' (those not poor enough to receive parish relief but too poor to be taxed), the inclusion of this significant but marginal strata of society was not accompanied by

${ }^{48}$ London Gazette, 16-20 August 1683, no. 1852; for the language of 'Nurseries of Sedition' see the address from Northampton, London Gazette, 3-6 September, 1683, no. 1857. The connection between corporations and sedition became a general trope of Tory political writing in the 1680s (see Nathaniel Johnston, The Excellency of Monarchical Government, Especially of the English Monarchy (1686), p. 414).

49 The exceptions in the 1683 addresses are the texts from the Grand Jury of Derbyshire, reputedly subscribed by 9175 individuals, (London Gazette, 13-17 December 1683, no. 1886) and that from the Stannery Courts of Cornwall, 'signed by about ten thousand Tinners' (London Gazette, 25-29 October, 1683, no. 1872). Contrast this reticence with the reporting of the numbers of subscribers to the addresses in defence of Charles II's dissolution of the Oxford Parliament in 1681: London Gazette, 30 June to 4 July 1681, no. 1630. Town and Port of Deal (362), Inhabitants of Great Marlow, (222); London Gazette, 4-7 July 1681, no 1631, Officers of Militia, other gentlemen and loyal inhabitants of Canterbury (400); London Gazette, 7-11 July 1681, no 1632, Inhabitants of Westminster and its liberty, ('signed by some thousands'); London Gazette 11-14 July 1681, no 1633, Brecon, (2700); 'Loyal Inhabitants' of Aylesbury (270); London Gazette, 15-18 July 1681, no 1634, Nobility, gentry, clergy and other freeholders of N. Riding of Yorkshire, (185).

${ }^{50}$ An issue acknowledged by publications such as Vox juvenilis: Or, the loyal apprentices vindication of the design and promoters of their late humble address to his majesty (1681 [2]) which attempted to counter Whig accusations that the apprentices subscriptions had been bought with bribes of food and drink. 
a similar inclusiveness with regards to gender. No women can be found on this return. ${ }^{51}$ The only women subscribers I have found on a surviving manuscript loyal address were the five women whose names feature on a 1696 loyal address to William III from Lancashire. ${ }^{52}$ Their presence, however, may be explained by the unusual nature of this address. The return was clearly intended to deliver the county's response to the demand that the public swear the Association to William III. This Association, modelled on the 1584 Bond of Association to Elizabeth I, demanded that subscribers declare that William was rightful and lawful king and promised to exact revenge should any attempt on the king's life prove successful. ${ }^{53}$ Yet, whereas in other areas, the Association was separated from the loyal address congratulating the king on surviving the assassination plot which had prompted its drafting, in Lancashire subscribers signed the text of the loyal address which incorporated the acknowledgment that William was 'rightfull \& Lawfull King'. 54

In general, however, women subscribers to the 1696 Association are rare. The largest county returns reported in the press, those for Suffolk, which were reputed to contain 70,000 names, feature only fourteen women subscribers. ${ }^{55}$ These were concentrated in just three of the twenty-four Suffolk Association rolls, most organised by hundred. ${ }^{56}$ Given the numbers alleged to have subscribed and estimates of contemporary population, the subscribers must then have included the majority of males, both juvenile and adult within the county. ${ }^{57}$ Indeed, some returns suggest a certain amount of anxiety about the eligibility of some male

${ }^{51}$ See Bodleian Library, Oxford, MS Rawlinson A61* fos 164-186v., discussed in Vallance, Loyalty, ch. 5 and a brief summary in Edward Vallance 'Cromwell's Trunks', The Historian, 137 (2018), pp. 34-36. My comments regarding the Hearth Tax are informed by Catherine Ferguson, 'The Hearth Tax and the Poor in PostRestoration Woking', in Trevor Dean, Glyn Parry and Edward Vallance (eds), Faith, Place and People in Early Modern England: Essays in Honour of Margaret Spufford (Woodbridge: Boydell and Brewer, 2018), ch. 6.

52 Wallace Gandy ed, Lancashire Association Oath Rolls 1696 (Society of Genealogists reprint, 1985), p. 4 (Rebecca Riselton of Halewood); p. 60 (Frances Edmondson of Borwich); p. 90 (Elizabeth Readhead of Blawith); p. 101(Aliz Nowell and Frances Turner of Clitheroe). Unusually, there are further Association rolls for Lancashire held locally rather than in the National Archives, but these only feature the names of local male officeholders see Lancashire Record Office, QDV/10

${ }^{53}$ On the Association see Vallance, Revolutionary England and the National Covenant, pp. 201-9; Pincus, 1688, pp. 463-71; David Cressy, 'Binding the Nation: The Bonds of Association, 1584 and 1696' in Delloyd J. Guth and John W. McKenna (eds), Tudor Rule and Revolution: Essays for G. R. Elton from His American Friends (Cambridge: Cambridge University Press, 1982), pp. 217-37.

54 TNA C213/138/1 for the Lancashire returns.

55 TNA C213/264. For more detail on the Suffolk returns see David Cressy, Literacy and the Social Order: Reading and Writing in Tudor and Stuart England (Cambridge: Cambridge University Press, 1980), pp. 98-105.

56 TNA C213/264/7, Babergh Hundred, (Melforde, Lawshall and Cavendish returns); C213/264/13, Thinge hundred, (Whepsted return: 'Mistris Min widow her marke'); C213/264/21, Stow hundred (Onehouse return). The exception to the organisation of returns by hundred is $C 213 / 264 / 24$, a single sheet roll of Suffolk magistrates taken at Beccles Quarter Sessions.

57 See Cressy, 'Binding the Nation', p. 231. The total population of the county in the 1670 s has been estimated at only 125,000, John Patten, 'Population distribution in Norfolk and Suffolk during the sixteenth and seventeenth centuries', Transactions of the Institute of British Geographers, 65 (1975), pp. 45-65.

Accepted manuscript version of E. Vallance, 'A Democratic Culture? Women, Citizenship and Subscriptional Texts in Early Modern England', in Democracy and Anti-democracy in Early Modern England, 1603-1689, ed. C. Cuttica and M. Peltonen (Brill, Leiden, 2019), ch. 12 
subscribers: that for Theberton parish in Blything hundred discriminated amongst the list of male names by identifying those who were servants, lodgers, 'Jornymen' and 'prentes' (apprentices). ${ }^{58}$ Subscribers to the St. Andrews, Ilketshall return were divided into 'Owners', 'Tenants', 'Single Persons' and 'Lodgers'. ${ }^{59}$ Similarly, in Ickworth in Thingoe Hundred, subscribers were divided between 'houskeepers' and 'Sarvants \& others' ${ }^{60}$ Some parish constables clearly continued tou hold to the view that only male householders should subscribe: the return for Great Wratting was headed 'The names of the Howse Hould ers [sic]'. ${ }^{61}$

The organisation of returns in this fashion seems to have been a result in part of the direction of the county's grand jury that constables should gather the subscriptions of all householders, lodgers and others within their parishes. ${ }^{62}$ Yet despite the direction from the grand jury to expand subscription beyond householders, it seems that this order was rarely interpreted to mean that adult women should also subscribe. The gendered assumption that women should not be included is also revealed on the return for the parish of Chelsworth which recorded that 'There are noe Persons in the ye Parish of Chelsworth aforesaid yt have refused to subscribe this Declaration', though the return only included the names of men. ${ }^{63}$ Similar statements appear regularly on the Suffolk parish Association returns, even in the hundred of Babergh which contained the largest number of women subscribers (eleven of the total fourteen). ${ }^{64}$ This suggests that presence of women subscribers probably reflected the assumptions of particular constables or the presence of significant female property holders in a locality. This seems to have been the case in the small village of Onehouse in Stow Hundred, where the two women subscribers, Mary Self and Susan Burmin, were listed as 'housekeepers'. ${ }^{65}$ We can observe similar assumptions at play in the administration of the Association elsewhere. Antony Riurs, the constable of Marsh Gibbon in Buckinghamshire, wrote that he

\footnotetext{
58 TNA C213/264/2.

59 TNA C213/264/10, Wangford hundred and see the return for St. Michaels in South Elom in the same hundred in which the all male subscribers are listed as either yeomen or 'singell man'.

${ }^{60}$ TNA C213/264/13.

${ }^{61}$ TNA C213/264/11, Risbridge hundred.

62 TNA C213/264/20, Blackbourne hundred. A number of the parish returns here include the text with this direction and direction to include full details (name, address and occupation) of refusers.

63 TNA C213/264/3.

${ }^{64}$ TNA C213/264/7, Waldingfield Magna ('none refuse'); Assington, ('None refuse within o[u]r parish').

65 TNA C213/264/21, Stow hundred, Onehouse return.
} 
thought it convenient at shuch a Junctur of time as this to bring in ye names of Servants and Labourous as wel as householders to show our Royalty [sic.] to King William. Let others hoalt be-twixt too opinions I thinke it my dewty and inturist to be for the present gournment. ${ }^{66}$

In Great Yarmouth, the corporation put considerable effort into securing subscriptions from as many people as possible. The Association was placed on display in the Tolhouse for six days while constables were instructed to urge the inhabitants of their wards to subscribe. This effort resulted in a Yarmouth roll with 1117 names upon it, 28\% of whom left marks rather than signed their names. However, no women were required or encouraged to subscribe. ${ }^{67}$

This suggests that if the fourteen female subscribers to the Suffolk Association rolls did assign themselves a political role, this was largely in the face of the view of local officialdom which continued to assume that only men would be required to give their hands. Indeed, as has been noted, some constables appear to have felt uneasy at the breadth of male subscription to the Association and carefully organised their returns to maintain social and economic distinctions between the subscribers. Two features of the 1696 Association explain the almost complete absence of women from the returns, despite the vast scale of subscription in some counties such as Suffolk: first, the legislation governing its administration targeted office-holders; and second subscription to the Association was directly connected to the use of violence (the promise to 'revenge' within the text which also caused problems for some male subscribers, notably Quakers). ${ }^{68}$ It was this, as much as women's political participation as a whole that Joseph Addison was satirising in his Freeholder articles on a 'Female Association' (his specific target here being the anti-Jacobite volunteer associations). ${ }^{69}$ For

${ }^{66}$ Quoted in Wallace Gandy, 'The Association Oath Rolls for Buckinghamshire, A. D. 1696', Records of Buckinghamshire, 11, 3 (1921), pp. 109-20, p. 115.

${ }^{67}$ Perry Gauci, Politics and Society in Great Yarmouth, 1660-1722 (Oxford: Clarendon Press, 1996), p. 190. Norfolk Record Office, Y/C/19/9, Yarmouth Corporation Assembly Book, 1680-1701, fos 273-273v., 12 March 1696; the Oxfordshire returns also appear to have been all male (see Jeremy Gibson, Politics and Loyalty in Post-Revolution Oxfordshire: The 1690 County Parliamentary Poll An edited transcript, The Association Oaths Rolls, 1696-6, Analysis (Oxford: Oxfordshire Family History Society in Association with the Family History Partnership, 2011), p. 5).

68 'William III, 1695-6: An Act for the better Security of His Maj[es]ties. Royal Person and Government. [Chapter XXVII. Rot. Parl. 7 \& 8 Gul. III.p.6.n. 1.]', in Statutes of the Realm: Volume 7, 1695-1701, ed. John Raithby (s.l: Great Britain Record Commission, 1820), 114-118. British History Online, accessed March 5, 2018, http://www.british-history.ac.uk/statutes-realm/vol7/pp114-118; TNA C213/264/17, Hartsmere hundred, Westhorpe parish, two local Quakers refused the Association on the grounds that they could not promise to 'revenge'.

69 Joseph Addison, The Freeholder, ed. James Leheny (Oxford: Clarendon Press, 1979), pp. 74-5. (Jan 16, 1716). For more on these associations see Frank O'Gorman, 'Origins and Trajectories of Loyalism in England,

Accepted manuscript version of E. Vallance, 'A Democratic Culture? Women, Citizenship and Subscriptional Texts in Early Modern England', in Democracy and Anti-democracy in Early Modern England, 1603-1689, ed. C. Cuttica and M. Peltonen (Brill, Leiden, 2019), ch. 12 
Addison, the women's 'Arms' were their ability to 'Smile or Frown to any Purpose'. Their feminine charms were deployed to secure male volunteers, as the virgin who subscribed 'fifteen Lovers, all of them good Men and true' or the wife who 'writ her own Name and one Vassal, meaning her Husband'. ${ }^{70}$ Addison was not simply making a mockery of the prominence of especially elite women in early eighteenth-century party politics, noted by Elaine Chalus amongst others, but drawing humour from the absurdity of women engaging in military service or acting as recruiting sergeants. ${ }^{71}$

If the connection to military service explains the limited appearance of women on the 1696 Association returns, the general absence of women from the list of subscribers to loyal addresses should be connected to their primary aim of representing public loyalty. So, whereas oaths and covenants bound subscribers to perform particular actions, addresses offered more generalised expressions of fidelity. As Mark Knights has noted, there was a tension in addressing activity between the desire to show addresses were authoritative, the production of official bodies such as grand juries, and that they were representative, enjoying widespread support, which could involve gathering subscriptions from non-office holders and those not formally enfranchised. ${ }^{72}$ Paradoxically, as both popular petitioning and addressing resurfaced during the Exclusion Crisis, the language of status became more, not less important, especially for the Whig party which was keen to distance itself from accusations that it was simply reviving the practices of the civil war. ${ }^{73} \mathrm{I}$ have argued elsewhere that the address came to replace the state oath as the main means of representing public loyalty in the eighteenth century. As Paul Langford observed, this was in part because nationwide campaigns to swear loyalty to the crown on pain of significant penalties for refusal did not sit well with the 'revolution principle' of voluntary association as the foundation of social and political life. ${ }^{74}$ The outcome of this theoretical emphasis upon government by consent was,

1580-1840', in Allan Blackstock and Frank O'Gorman (eds), Loyalism and the Formation of the British World, 1775-1914 (Woodbridge: Boydell and Brewer, 2014), ch. 2.

${ }^{70}$ Addison, The Freeholder, pp. 87-90.

${ }^{71}$ Elaine Chalus, "Women are often very good scaffoldings": Women and Politics in the Age of Anne', Parliamentary History, 28:1 (2009), pp. 150-65; Eirwen Nicholson, 'Sacheverell's Harlots: Non-Resistance on Paper and in Practice', Parliamentary History, 31:1 (2012), pp. 69-79.

72 Knights, Representation and Misrepresentation, pp. 136-42. Some addresses attempted to resolve this conundrum by effectively creating a hierarchy of subscribers, from local officials, the aristocracy and gentry, to freeholders and mere 'inhabitants'. For an example, see London Gazette, 6-9 August 183, no. 1849, 'address of Monmouth justices of peace and grand jury and other Your Majesty’s Loving Subjects'.

${ }^{73}$ Vallance, Loyalty, ch. 7.

74 Paul Langford, Public Life and the Propertied Englishman, 1689-1798 (Oxford: Oxford University Press, 1991), pp. 98-114; Vallance, 'Women, Politics and the 1723 Oaths', pp. 997-999. 
ironically, to reduce the opportunities for women to formally participate in the political process, as they had often done in public oath-taking.

This chapter has argued for a focus upon partisanship and political and military mobilisation, rather than citizenship and proto-democratic politics, in understanding the presence of women on subscriptional texts in early modern England. Of course, military mobilisation has been seen by modern historians as a key driver of democratic change. Broader analyses of the development of democracy in Europe have argued that citizenship was part of the bargain that states struck with their peoples as changes in warfare and military technology necessitated mass armies in the nineteenth and twentieth-century. ${ }^{75}$ The chronology here, however, is important: Zaret's focus on communicative practices such as petitioning suggests that a democratic political culture developed in mid-seventeenth-century England and was sustained into the eighteenth century. Yet, the emergence of mass democracies has been a relatively recent phenomenon and their existence appears increasingly insecure. ${ }^{76}$ Moreover, the evidence of the Suffolk Association rolls suggests that arguments regarding the inter-relationship between the growth of the state and the expansion of the political nation should be treated with caution in an early modern context as well. Steven Pincus has argued that there was a qualitative as well as quantitative difference between the Association of 1696 and its Elizabethan predecessor of 1584. For Pincus, the Williamite Association demonstrates that the kingdoms William III governed were "very different both socially and politically from those governed by Elizabeth I' ${ }^{77}$ The greater scale of the Williamite Association is undeniable. As we have seen, however, the idea that it was only the propertied male householder who exercised political rights proved highly resilient, even in the face of mass exercises in surveying public loyalty. Indeed, earlier loyalty tests, namely the Protestation, if narrower in scope than the Association, may nonetheless have seen greater female participation: Walter suggests that surviving records may even

\footnotetext{
${ }^{75}$ See for example Charles Tilly, 'Where Do Rights Come From?' in Theda Skocpol et al. (eds), Democracy, Revolution and History (Ithaca and London: Cornell University Press, 1998), ch. 3.

76 John Dunn, 'Conclusion', in John Dunn (ed.), Democracy: The Unfinished Journey: 508 BC to AD 1993 (Oxford: Oxford University Press, 1992), ch. 13, pp. 239-40. In a British context see Robert Saunders, 'Democracy', in David Craig and James Thompson (eds), Languages of Politics in Nineteenth-Century Britain (Basingstoke: Palgrave Macmillan, 2013), pp. 142-67.

${ }^{77}$ Pincus, 1688, p. 464.
} 
underestimate women's involvement in this case if, as in the case of the Scottish National Covenant, women swore but did not subscribe the Protestation. ${ }^{78}$

Neither has this chapter sought to deny that women did occasionally use these texts to advance political claims and assert their own right to petition. As Melissa Mowry has recently shown, Leveller women employed the group's language of commonality and collectivity to assert their own agency. ${ }^{79}$ Such claims, however, were relatively rare. Some women's petitioning activity certainly was highly transgressive, challenging class-based and gendered assumptions about who should comment on matters of church and state. Laura Stewart has pointed out, though, that the participation of women in politically or religiously controversial activity (such as the Prayer Book riot at St. Giles Church, Edinburgh in 1637) might have been encouraged precisely so as to cover a rebellious and or revolutionary intent by having supposedly 'simple' women take the lead. ${ }^{80}$ In addition, the right of women to petition in general was not in question as the right to petition did not imply that the petitioner possessed the characteristics of a citizen. As both Whiting and Waddell have suggested, instead petitioning activity actually legitimated inequality through its emphasis on deference to and dependence upon authority. The enduring vitality of petitioning as a popular form might then be explained not by its subversive potential, nor by its capacity to act as a vehicle for democratic impulses, but because of the persistence of social and political inequality. As Peter Jones and Steven King have argued with reference to pauper petitions in the modern era:

As long as the structural conditions of dominance and the socio-economic hierarchy remained broadly analogous, the private petition would have (and indeed, always has had) its part to play as an intercessionary form. $^{81}$

Women's active participation in the political arena was not predominantly framed by rights-based claims but by arguments grounded on their loyalty. This was true in petitioning activity as well as oath-taking: women petitioners for relief during the civil wars and after needed to demonstrate political loyalty (of the appropriate kind), in order to secure

\footnotetext{
${ }^{78}$ Walter, Covenanting Citizens, pp. 203-7. I am grateful to John Walter for discussing these points with me.

${ }^{79}$ Melissa Mowry, "CCommoners Wives who stand for their Freedom and Liberty": Leveller Women and the Hermeneutics of Collectivities', Huntington Library Quarterly, 77:3 (2014), pp. 305-24.

${ }^{80}$ Stewart, Rethinking the Scottish Revolution, p. 58.

${ }^{81}$ Peter Jones and Steven King, 'From Petition to Pauper Letter: the Development of an Epistolary Form', in Peter Jones and Steven King (eds), Obligation, Entitlement and Dispute under the English Poor Laws (Newcastle upon Tyne: Cambridge Scholars Publishing, 2015), ch. 3, p. 63.
} 
concessions. ${ }^{82}$ Yet, it was not simply the practical needs of regimes in moments of crisis which provided women with opportunities for political engagement. As has already been noted, both historians and philosophers have recognised the affective and subjective quality of loyalty and its distinctiveness as a value from 'rule-governed' forms of political obligation. ${ }^{83}$ The idea of loyalty could cut across distinctions of gender and social status, replacing them instead with a shifting boundary between the loyal and disloyal. The critical division in subscriptional texts was often then not between citizen and non-citizen, male or female but between, the 'well-affected' and the 'malignant', 'us' and 'them'.

${ }^{82}$ See on this Hannah Worthen, 'Supplicants and Guardians: the Petitions of Royalist Widows during the Civil Wars and Interregnum, 1642-1660', Women's History Review, 26:4 (2017), pp. 528-40.

${ }^{83}$ Shklar, 'Obligation, Loyalty and Exile', pp. 40-1. 